\title{
Correlation of Epithelial Cell Abnormality in Cervical Cytology with Cervical Histology
}

\author{
Shrestha $R^{1}$, Sinha $K^{2}$, Sharma $N^{2}$, Shrestha $A^{3}$
}

\section{ABSTRACT}

Introduction: Cervical cancer is the second most common cancer in females worldwide and third most common cancer in Nepal. Conventional Pap smear is the most widely used screening tool for detecting premalignant and malignant lesions of cervix. Cytohistological correlation of Pap smear is a widely accepted method for analysis of various factors leading to discrepancies in diagnosis and internal quality assurance. Aim: To study the cytohistological correlation of epithelial cell abnormality in Pap smear in Nepalgunj Medical College Teaching Hospital, Kohalpur, Banke, Nepal. Methods: This is a hospital based prospective cross sectional study carried out at Department of Pathology, NGMC, Kohalpur, Nepal from August 2018 to January 2020. The study included 137 cases of Pap smear with epithelial cell abnormality and correlated with corresponding histopathological findings. Results: The age of patients ranged from 20-80 years with the number of cases seen in the range of 30-39 years ( $\mathrm{n}=44$; $32.1 \%$ ). Whitish discharge per vaginum was most common presenting symptom. High grade squamous intraepithelial lesion (HSIL) was the most common abnormal finding in Pap smear with a frequency of 40 (29.1\%) cases. Out of 137 cases of Pap smear 57 (41.6\%) cases showed discrepancies in cervical biopsy. All cases of Squamous Cell Carcinoma (SCC) were correctly diagnosed by Pap smear. The overall sensitivity of smear test was $84 \%$. After evaluating cytohistological correlation, the Positive Predictive Value (PPV) was found to be $100 \%$ for SCC, $52 \%$ for HSIL and $59 \%$ for Low grade squamous intraepithelial lesion (LSIL). Conclusion: The current study revealed a good correlation between cervical cytology and biopsy in Pap smear showing epithelial cell abnormalities. Thus, cytology and histology are complementary to each other and helps to reduce discrepancies.

Keywords: Cytohistological correlation, High grade squamous intraepithelial lesion, Low grade squamous intraepithelial lesion, Pap smear

Authors:

1. Dr. Richa Shrestha

2. Dr. Kavita Sinha

3. Dr. Nirmala Sharma

4. Dr. Anil Shrestha

${ }^{1}$ Department of Pathology, Nepalgunj Medical College and Teaching Hospital, Kohalpur, Banke

${ }^{2}$ Department of Obstetrics and Gynaecology, Nepalgunj Medical College and Teaching Hospital, Kohalpur, Banke

${ }^{3}$ Department of Medicine, Nepalgunj Medical College and Teaching Hospital, Kohalpur, Banke

\section{Address for Correspondence:}

\author{
Dr. Richa Shrestha \\ Department of Pathology \\ Nepalgunj Medical College and Teaching Hospital \\ Kohalpur, Banke, Nepal \\ Email: shrestharicha@hotmail.com
}

\section{INTRODUCTION}

Cancer of the cervix is the second most common cancer in developing countries following breast cancer and ranks fourth globally. ${ }^{1}$ It is third common cancer in females in Nepal. ${ }^{2}$ Human Papilloma Virus (HPV) is considered as the primary factor in the development of cervical cancer. Poor living condition, lack of hygiene, early age of first intercourse, multiple sexual partner are other etiological factors. ${ }^{3}$ Cervical cytology using the Papanicolaou (Pap) smear is most commonly used cervical cancer screening method in developing countries, despite of other advanced tests for high risk HPV, which is not available widely. A significant decrease in the incidence and mortality of cervical cancer is due to effective cervical cytology screening program.Although cervical cytology is considered effective for screening of precancerous conditions of cervix, its false negative yield due to sampling and interpretation error is still a reason of concern. Thus histological correlation of Pap smear is one of the recommendations of the European guideline for quality reassurance to reduce false negative results. ${ }^{4}$

Thus the present study has been carried out to evaluate the cytohistological correlation of cervical lesion in Pap smears with epithelial cell abnormalities. 


\section{METHODS}

This is a hospital based descriptive study conducted over the period of August 2018 to January 2020 in Department of Pathology, NGMC, Kohalpur, Banke, Nepal. Informed verbal consent from the patient and permission of the institutional review committee (IRC) of the hospital was also obtained. Total 137 Pap smears with epithelial cell abnormality were included in the study whose corresponding histopathological sample was also received in the form of cervical biopsy or hysterectomy performed for various indications. The study group included women of different age group who were attending gynecology outpatient department (OPD).

\section{Inclusion Criteria}

- Epithelial cell abnormality in Pap smear.

- Cervical biopsy on the corresponding patient for histopathological study.

\section{Exclusion Criteria}

- Negative for Intraepithelial lesion and Unsatisfactory smears for evaluation in Pap cytology.

- Epithelial cell abnormality in Pap smear without cervical biopsy of same patient.

The Pap smears were taken with the Ayer's spatula on a clean glass slide and fixed immediately in $95 \%$ ethanol and ether. ${ }^{5}$ Staining of the slides were performed by means of the conventional Pap technique and was reported according to the Bethesda for cervical cytology 2014 and biopsies were advised for correlation. Tissue sample obtained was fixed in $10 \%$ neutral buffered formalin and processed routinely with final embedding in paraffin blocks and stained with hematoxylin and eosin (H\&E). ${ }^{6}$ Biopsy results were evaluated with the Cervical Intraepithelial Neoplasia (CIN) classification and the correlation with Pap smear was studied.

Biopsy reports were categorized as nonneoplastic (cervicitis, polyps and immature squamous metaplasia), CIN I (LSIL), CIN II and CIN III (HSIL) and Invasive carcinoma according to World Health Organization (WHO) classification. ${ }^{7}$ Pap smear cytology reports were categorized according to Bethesda for cervical cytology- 2014. ${ }^{8}$ Data were analyzed using Microsoft excel 2010 and standard statistical software SPSS 20.0.

\section{RESULTS}

A total of 137 cases were included in the study. All of them had abnormal Pap smear finding that fulfilled the epithelial cell abnormality criteria according to the Bethesda -2014. The peak age group was between $30-39$ years (44 cases, $32.1 \%$ ), as shown in table I. The mean age of the patient was 38.5. The most common presenting complain was whitish discharge per vagina (52\%) followed by pain lower abdomen (40\%). There were 37 (26.9\%) cases of Low grade squamous intraepithelial lesion (LSIL), 40 (29.1\%) cases of High grade squamous intraepithelial lesion (HSIL), 30 (22\%) cases of Atypical squamous cell of undetermined significance (ASC-US), 13 (9.6\%) cases of Atypical squamous cells cannot exclude a highgrade squamous intraepithelial lesion (ASC-H), 7 (5.2\%) cases of Atypical Glandular cells Not otherwise specified (AGCNOS), and $10(7.3 \%)$ cases of Squamous cell carcinoma (SCC) on Pap smear cytology. On histopathology, there were $22(16.1 \%)$ Nonneoplastic cases, 40 (29.1\%) CIN I cases, 20 (14.7\%) CIN II cases, 25 (18.2\%) CIN III cases, 28 (20.4\%) SCC and 2 (1.5\%) Adenocarcinoma (Table II). Out of 30 cases of ASC-US, 16 was CIN I followed by 8 nonneoplastic cases on histopathology. Out of 37 LSIL in Pap smear, 22 was CIN I in biopsy. Including both HSIL and ASC-H ( 40 and 13 cases respectively), 27 were accurately diagnosed as CIN II and III in biopsy (11 and 16 cases respectively). All 10 SCC in Pap smear was diagnosed as invasive SCC in biopsy. Out of 7 AGCNOS, 2 were adenocarcinoma. The most common histopathological finding was CIN I (40 cases; 29.1\%) followed by SCC and CIN III ( 28 cases; $20.4 \%$ and 20 cases; $14.7 \%$ respectively). The correlation of malignancy in Pap smear with histopathology was statistically significant with $p$ valve of $<0.001$. The sensitivity of cytology was $84 \%$ with false positivity of $16 \%$. We were unable to calculate specificity, and negative predictive value as there were no real negative or false negative cases in cytology.

The correlation was calculated using Positive Predective Value (PPV) in our study data and showed increased cytohistological correlation with $\mathrm{CIN}$ as the degree of epithelial cell abnormality increased. This was matched based on the Bethesda terminology counterpart of the smear result with CIN terminology of the biopsy result. The PPV was $100 \%$ for SCC, $52 \%$ for HSIL , $59 \%$ for LSIL and 28\% for AGCNOS (Table III). Out of 137 cases, 80 cases (58.4\%) showed concordance between Pap smear and cervical biopsy while discrepancies was seen in 57 (41.6\%) cases (Table IV).

\begin{tabular}{|c|c|c|}
\hline Age (Year) & Frequency & $\%$ \\
\hline $20-29$ & 8 & $5.9 \%$ \\
\hline $30-39$ & 44 & $32.1 \%$ \\
\hline $40-49$ & 37 & $27.0 \%$ \\
\hline $50-59$ & 36 & $26.3 \%$ \\
\hline $60-69$ & 11 & $8.0 \%$ \\
\hline $70-80$ & 1 & $0.7 \%$ \\
\hline TOTAL & 137 & $100 \%$ \\
\hline
\end{tabular}




\begin{tabular}{|c|c|c|c|c|c|c|c|c|}
\hline \multirow{2}{*}{$\begin{array}{c}\text { Pap } \\
\text { Smear } \\
\text { Diagnosis }\end{array}$} & \multicolumn{7}{|c|}{ Histopathological Diagnosis } & \multirow{2}{*}{$\frac{9}{\frac{2}{\pi}}$} \\
\hline & $\begin{array}{c}\text { Non- } \\
\text { Neoplastic }\end{array}$ & CIN I & CIN II & CIN III & scc & $\begin{array}{c}\text { Adeno- } \\
\text { carcinoma }\end{array}$ & Total & \\
\hline LSIL & $\begin{array}{c}8 \\
(5.8 \%)\end{array}$ & $\begin{array}{c}22 \\
(16.0 \%)\end{array}$ & $\begin{array}{c}7 \\
(5.1 \%)\end{array}$ & $\begin{array}{c}0 \\
(0.0 \%)\end{array}$ & $\begin{array}{c}0 \\
(0.0 \%)\end{array}$ & $\begin{array}{c}0 \\
(0.0 \%)\end{array}$ & $\begin{array}{c}37 \\
(26.9 \%)\end{array}$ & \\
\hline HSIL & $\begin{array}{c}2 \\
(1.5 \%)\end{array}$ & $\begin{array}{c}1 \\
(0.7 \%)\end{array}$ & $\begin{array}{c}7 \\
(5.1 \%)\end{array}$ & $\begin{array}{c}14 \\
(10.1 \%)\end{array}$ & $\begin{array}{c}16 \\
(11.6 \%)\end{array}$ & $\begin{array}{c}0 \\
(0.0 \%)\end{array}$ & $\begin{array}{c}40 \\
(29.1 \%)\end{array}$ & \\
\hline ASCUS & $\begin{array}{c}8 \\
(5.8 \%)\end{array}$ & $\begin{array}{c}16 \\
(11.7 \%)\end{array}$ & $\begin{array}{c}4 \\
(3.0 \%)\end{array}$ & $\begin{array}{c}2 \\
(1.5 \%)\end{array}$ & $\begin{array}{c}0 \\
(0.0 \%)\end{array}$ & $\begin{array}{c}0 \\
(0.0 \%)\end{array}$ & $\begin{array}{c}30 \\
(22.0 \%)\end{array}$ & 5 \\
\hline $\mathrm{ASCH}$ & $\begin{array}{c}0 \\
(0.0 \%)\end{array}$ & $\begin{array}{c}0 \\
(0.0 \%)\end{array}$ & $\begin{array}{c}2 \\
(1.5 \%)\end{array}$ & $\begin{array}{c}9 \\
(6.6 \%)\end{array}$ & $\begin{array}{c}2 \\
(1.5 \%)\end{array}$ & $\begin{array}{c}0 \\
(0.0 \%)\end{array}$ & $\begin{array}{c}13 \\
(9.6 \%)\end{array}$ & $\mathrm{v}$ \\
\hline AGCNOS & $\begin{array}{c}4 \\
(3.0 \%)\end{array}$ & $\begin{array}{c}1 \\
(0.7 \%)\end{array}$ & $\begin{array}{c}0 \\
(0.0 \%)\end{array}$ & $\begin{array}{c}0 \\
(0.0 \%)\end{array}$ & $\begin{array}{c}0 \\
(0.0 \%)\end{array}$ & $\begin{array}{c}2 \\
(1.5 \%)\end{array}$ & $\begin{array}{c}7 \\
(5.2 \%)\end{array}$ & \\
\hline scc & $\begin{array}{c}0 \\
(0.0 \%)\end{array}$ & $\begin{array}{c}0 \\
(0.0 \%)\end{array}$ & $\begin{array}{c}0 \\
(0.0 \%)\end{array}$ & $\begin{array}{c}0 \\
(0.0 \%)\end{array}$ & $\begin{array}{c}10 \\
(7.3 \%)\end{array}$ & $\begin{array}{c}0 \\
(0.0 \%)\end{array}$ & $\begin{array}{c}10 \\
(7.3 \%)\end{array}$ & \\
\hline TOTAL & $\begin{array}{c}22 \\
(16.1 \%)\end{array}$ & $\begin{array}{c}40 \\
(29.1 \%)\end{array}$ & $\begin{array}{c}20 \\
(14.7 \%)\end{array}$ & $\begin{array}{c}25 \\
(18.2 \%)\end{array}$ & $\begin{array}{c}28 \\
(20.4 \%)\end{array}$ & $\begin{array}{c}2 \\
(1.5 \%)\end{array}$ & $\begin{array}{c}137 \\
(100 \%)\end{array}$ & \\
\hline
\end{tabular}

Table II: Correlation of Pap smear and histopathological diagnosis with P valve

\begin{tabular}{|ccc|}
$\begin{array}{c}\text { Cytopathological } \\
\text { Diagnosis }\end{array}$ & $\begin{array}{c}\text { Histopathological } \\
\text { Diagnosis }\end{array}$ & PPV \\
\hline LSIL & CIN I & $59 \%$ \\
\hline HSIL & CIN II \& III & $52 \%$ \\
\hline SCC & SCC & $100 \%$ \\
\hline AGCNOS & Adenocarcinoma & $28 \%$ \\
\hline
\end{tabular}

Table III: Positive Predictive Values of cyto-histopathologic diagnosis

\begin{tabular}{|cccc|}
\hline Pap Smear Diagnosis & Concordant Cases & Discordant Cases & Total cases \\
\hline LSIL & 22 & 15 & 37 \\
\hline HSIL & 21 & 19 & 40 \\
\hline ASCUS & 16 & 14 & 30 \\
\hline ASCH & 9 & 4 & 13 \\
\hline AGCNOS & 2 & 5 & 7 \\
\hline SCC & 10 & 0 & 10 \\
\hline TOTAL & $\mathbf{8 0}$ & $\mathbf{5 7}$ & $\mathbf{1 3 7}$ \\
\hline
\end{tabular}

Table IV: Concordance and discordance cases between Pap smear and cervical biopsy

\section{DISCUSSION}

Most of the cervical cancer arises from the transformation zone, which can be detected by a good Pap smear. The Pap smear is regarded as an ideal screening tool worldwide for sexually active women. ${ }^{9-11}$

Cervical Pap smear is a widely used screening test as it is simple and cost effective in developing countries like Nepal. The aim of cervical screening test is to enable early detection and treatment of precancerous and cancerous lesion and prevent mortality due to cervical cancer. However, it has a high false negative rate ranging from $1.1-30 \%$, as shown in various studies. ${ }^{12,13}$ This is due to variation in sampling technique, smear preparation and difference in impression among expertise. Thus, comparing cytological impression with cervical biopsy is considered as immediate gold standard method to reduce the false negative rate.
This study is done to enhance the role of Pap smear in gynaecology cytology and its correlation with biopsy which provides important information regarding resolving the discrepancies or confirming the diagnosis by histology. ${ }^{14}$ In the present study, maximum number of cases were in the age group 30-39 years (41 cases), which is similar to studies done by Bamanikar SA et al, Likhar KS et al, Kaveri SB et al and Joshi et al. ${ }^{15-18}$ Whitish discharge per vaginum was the most common presenting symptom as reported in other similar studies. ${ }^{16-18} \mathrm{In}$ this study, HISL was the most common abnormal finding in Pap smear with $29.1 \%$ of all smears examined. Similar observations were made by Shah $\mathrm{R}$ et $\mathrm{al}^{19}$ and Fatima NK et al ${ }^{14}$, followed by LSIL in 37 (26.9\%) and ASCUS in 30 (21.2\%). Most common histopathological diagnosis among women with abnormal Pap smear was CIN I which accounted for 40 (29.1\%) of cases. Similar finding was observed in other studies. ${ }^{3,14,18,20-22}$ All 10 cases of SCC on PAP smear were diagnosed as invasive SCC in histopathology. Similar observation was made by Fathima NK et a $\mathrm{al}^{14,}$ Joshi $\mathrm{C}$ et $\mathrm{al}^{18}$, Abali $\mathrm{R}$ et $\mathrm{al}^{20}$ and Poudel $\mathrm{A}$ et al. ${ }^{21}$

We found nonneoplastic changes in 8 cases, CIN I in 16 cases, CIN II in 4 cases and CIN III in 2 cases of total 30 ASC-US cases. The total rate of CIN among cases with an ASC-US smear result was $73 \%$. The cases with ASC-H diagnosis in PAP smear was diagnosed as CIN II in 2 cases, CIN III in 9 cases and SCC in 2 cases by biopsy. The higher rate of CIN in cases reported as ASCUS and ASC-H in Pap smear indicated a need of close follow up and cervical biopsy in these patients. This observation was also seen in a study done by Abali $R$ et al. ${ }^{20}$ The false positive cases in this study showed chronic cervicitis or inflammation related regenerative changes which increased the rate of smear reported as ASC-US.

This study showed increased cytohistological correlation with Cervical Intraepithelial lesion as the degree of epithelial cell abnormality increased in Pap smear which is similar to study done by Abali $\mathrm{R}$ et al. ${ }^{20}$ In this study, concordance and discordance between Pap smear and histopathology is $58.4 \%$ and $41.6 \%$, with the increased concordance rate, which is also seen in study done by Poudel A et al ${ }^{21}$, Jain $\mathrm{RV}^{22}$ and Jyothi $\mathrm{R}$ et al. ${ }^{23}$

\section{LIMITATIONS}

Limitation of this study is that all the biopsies were not performed using colposcopy, which could cause error in identifying most suspicious area of cervix for taking biopsy and histopathological study resulting in false negative diagnosis. Thus colposcopy and colposcopy guided biopsy of cervix should be used along with Pap smear for increasing the accuracy of detection of cervical lesion. 


\section{CONCLUSION}

Pap smear is an ideal screening test for detection of precancerous and cancerous cervical lesion. However, under certain conditions, it may give false positive impression of neoplasia. Thus, it is necessary to perform a cervical biopsy which is considered to be the gold standard in cases of epithelial cell abnormality in Pap smear. The current study result supported a good correlation between cervical cytology and histopathology concluding that conventional Pap smear is a cost effective, simple and quick method of detection of precancerous and cancerous cervical lesion.

\section{REFERENCES}

1. GLOBOCAN 2018 (IARC), Section of cancer information (12/9/2018) WHO, 2018; GLOBOCAN 2018 database, IARC.

2. Population based cancer registary in Nepal, IARC, Interim analysis of data, Nov 2018.

3. Patil PR, Jibhkate SN. Cytohistopathological correlation of Papanicolaou smears: a hospital based study. Int J Reprod Contracept Obstet Gynecol 2016;5:1695-9.

4. Wiener, HG, Klinkhamer P, Schenck U, Arbyn M, Bulten J, Bergeron $C$, et al. European guidelines forquality assurance in cervical cancer screening: recommendations for cytology laboratories. Cytopathology. 2007;18(2):67-78.

5. Koss LG, Melamed MR. Koss Diagnostic Cytologty and its histopathological bases Vol I. $5^{\text {th }}$ ed America: Lippincot 2006; 1591-93.

6. Bancroft DJ. Theory and Practices of Histological Techniques. 7th ed. India: Elsevier; 2013. p 105-123.

7. Rosai J. Rosai and Ackerman's surgical pathology. Vol II, $10^{\text {th }}$ ed London: Elsevier 2011; 1444-57.

8. Nayar R, Wilbur DC. The Bethesda system of reporting cervical cytology. $3^{\text {rd }}$ ed USA: Springer 2015; xiii-xv.

9. Imtiaz F, Hasa WHG, Klinkhamer P, Schenck U, Arbyn M, Bulten $\mathrm{J}$, et al. European guidelines for quality assurance in cervical cancer screening: recommendations for cytology laboratories. Cytopathology.2007;18(2):67-78.

10. Saslow D, Runowicz CD, Solomon D, Moscicki AB, Smith RA, Eyre $\mathrm{HJ}$, et al. American Cancer Society Guidelines for the early detection of Cervical neoplasia and cancer. CA Cancer. 2002; 52:342-62.

11. Sawaya GF, Brown AD, Washington AE, Garber AM. Clinical practice: current approaches to cervical cancer screening. N Engl J Med. 2001; 344:1603-7.

12. Chhabra Y, Behera BG, Khalkho J, Pati N. Cytomorphological study of PAP smears in precancerous And cancerous lesions. J Cytol 2003; 20(2):64-7.

13. Ozkara SK, Yıldız K. Retrospective five year analysis of our cervicovaginal cytology screening programme under the perspective of Bethesda-2001. Turkish Bulletin of Pathology. 2002;19:119-24.
14. Fathima NK, Patil AM, Patil S, Sajjanar BB, Yendigeri SM, Arifulla K. Cyto- histological correlation of cervix lesion. UJMDS 2016, 04 (01): 28-30.

15. Bamanikar SA, Baravkar D, Chandanwale S, Dharwadkar A, Paranjape S. Study of cervical cytology and its correlation with clinical and histopathological findings. Clin Cancer Investig J 2016;5:403-8

16. Likhar KS, Saluja A, Gupta SG, Hazari RA, Likhar SK. Precancerous and cancerous lesions of cervix diagnosed by Pap's smear - A hospital based study. J Evol Med and Dent Sci 2014;3:1899-904

17. Kaveri SB, Khandelwal S. Role of Pap smear $N$ cervical biopsy in unhealthy cervix. J Sci Innov Res 2015;4:4-9

18. Joshi C, Kujur P, Thakur N. Correlation of Pap Smear and Colposcopy in Relation to Histopathological Findings in Detection of Premalignant Lesions of Cervix in A Tertiary Care Centre. Int J Sci Stud 2015;3(8):55-60.

19. Shah R, Thapa M. Correlation of cervical cytology with cervical histology.Kathmandu Univ Med J (KUMJ) 2005, JulSep;3(3):222-4.

20. Abali R, Bacanakgil BH, Celik S, Aras O, Koca P, Boran B, Dursun N. Histopathological Correlation of Squamous Cell Abnormalities Detected on Cervical Cytology. Turkish Journal of Pathology2011; 27( 2): 144-148.

21. Poudel A, Dahal P. Cytohistological correlation of conventional Papanicolaou smears in cervical neoplasia at a tertiary care hospital of Nepal. J Pathol Nep 2019;9:1475-9.

22. Jain RV. Screening for Carcinoma Cervix with Simultaneous use of PAP smear, colposcopy guided cervical biopsy-A prospective study. Pariplex -Indian journal of research. 2018;6(4):7-8.

23. Jyothi R, Gupta P, Rao R, Sood PL, Parasher N. Correlation between Colposcopy, Cytology and Histopathology in Highrisk Patients for Cervical Cancer in Perimenopausal Women in Himachal Pradesh, India. Journal of SAFOMS. 2013;1:21. 